\title{
The Negative Influence of Network Language and the Analysis of Countermeasure on College Students' Ideological Education
}

\author{
Ning Ning \\ School of Management, Anhui Jianzhu University, Hefei, China
}

\begin{abstract}
Network language is its different distinct characteristics from the traditional language. It has great influence on the ideological education in Colleges and universities. Through the analysis of the negative influence of network language on the contemporary college students and its cause of formation, starting from the educators, students and network three respects, this paper puts forward the path optimization of network language, in order to improve the effectiveness of College Students' Ideological education.
\end{abstract}

KEYWORD: Network language; College students; Ideological education

With the development of science and technology, the Internet obtains the popularization in a very rapid speed in the global, the network language is more and more attention becoming a form of language different from the traditional media. As main practitioners and dissemination of network language, The impact of college students is also more farreaching because of the influence of network language. Therefore, how to grasp the network language and the characteristics of college students in the internet age, innovation the pattern of ideological and political education, becomes the new task for the ideological and political education workers.

\section{THE NEGATIVE INFLUENCE OF NETWORK LANGUAGE ON COLLEGE STUDENTS' IDEOLOGICAL EDUCATION}

Due to the factors of the nature of the internet, college students' physical and mental characteristics, the network language showed the collision of different ideology and ideological culture. Many non-moral and non-rational network language penetrate into the college students' life gradually, and it increases the difficulty of the ideological education in Colleges and universities.

\subsection{Weakening college students' mainstream values}

At present, our country is in the period of social transformation and cultural reconstruction, many unhealthy network language produces a great impact and challenges to the traditional culture, contemporary college students are already accustomed to the network language to life, most of the network language is changed the original meaning of words, words derived solutions, with random and negative characteristics vulgar, without restraint plus. It leads many immoral network language and behavior, violence of language. This results to lost life goal, course and misjudge the value choice, these severely shaken ideals, beliefs of college students and miscarriage of justice on value choice, and effect the formation of the mainstream positive value view.

\subsection{Forming communication barriers between object and object of education}

Ideological and political education of more traditional language, this large and college students commonly used network language differences, which makes the content of Ideological and political education of college students is difficult to integrate into the language environment, conflicts and students recognized the network language and cultural psychology, college students from the heart to the ideological and political education rejection, conflict, aversion. At the same time, ideological and political education of college students do not understand the current ways of thinking and mental status, the subject of education leading role in 
education object will be greatly weakened, so that not only affects the in-depth exchanges in education the main object, but also lead to educational activities into AC bottle neck dilemma, caused the main object of the communication barrier.

\subsection{Restraining college students to form a healthy social life attitude}

Network language without restriction without management state, which makes the uncivilized network language was often used to go all lengths of College students. For example: "WBD" ("Son of a bitch")、"P" ("Fart")、TMD"("Fucking") and so on, Has the straightforward expression language out of euphemism, and even the emergence of other privacy disclosure insults, slander mutually, no restraint on the network. In addition to these not civilized language, there are many pornographic information pollution of the environment of University campus. Students in the full enjoyment of network language of pleasure at the same time, will be gradually formed in the network indulgence, lying, disinformation, irresponsible and other bad habits to real life. This has seriously affected the contemporary college students to form a healthy social life attitude.

\section{THE CAUSE OF THE NEGATIVE INFLUENCE ON NETWORK LANGUAGE}

Network language has produced negative influence on College Students' ideological and political education, its reason is mainly reflected in these aspects:

\subsection{The factors of college student}

One of the characteristics of Internet language is a prerequisite for simple and convenient, time-saving, make personal emotions to get as far as catharsis, and personal expression of heart. Many college students will face the academic crisis, interpersonal relationship, emotional confusion, the employment difficulties and pressure, unable to release multiple pressures in bear, will use extreme, extreme network language to give vent to their inner dissatisfaction, to experience the release of emotions of pleasure, to achieve the purpose of relaxation and regulation. Is based on the original, so that their use in network language, less consideration to the language itself shortcomings, such as bad words, derogatory, vulgar, and some are even in conflict with the mainstream value of the society.

\subsection{The factors of language differences of subject and object}

The traditional form of language features of ideological education is reflected in the norms, seriousness, stability. Which word is extremely exquisite and the terminology standard, that principle, position and direction, and the language is also less innovation. But the network language and its sharp contrast, characteristics of volatility, life oriented, innovative. The continuous development of Internet information technology to drive the network language is constantly changing, development and renewal of old words, appear to be eliminated, new words emerge in an endless stream, language more highlights the living characteristics. This caused the subject and the object of Ideological and political education body generation gap effect in communication.

\subsection{The factors of internet communication}

The openness of the Internet has led to the arbitrary words and behavior of college students, they can dress up any character in a chat room, micro-blog, forum and other public speech space, no scruples to speak one's mind freely, even reckless talk. The anonymity of the Internet will make them not for their own network behavior and responsibility, diluted the consciousness of network moral responsibility and legal responsibility for their. From a certain perspective, openness and interactivity features such as network lead to the spread of unhealthy network language.

\section{THE PATH OF OPTIMIZING THE NETWORK LANGUAGE AND IMPROVING COLLEGE STUDENTS' IDEOLOGICAL EDUCATION}

Facing the negative influence of network language on students produce, optimize the network language students, enhance the effectiveness of Ideological and political education be imperative.

\subsection{Educators strengthen the network language ability}

As educators, to keep pace with the times, pioneering and enterprising, only to improve the language ability of the network, to better guide the students scientific, reasonable use of network language. 


\subsubsection{Familiaring the network language}

The reasons of education between the subject and the object of discourse divide to produce, is that students used the Internet language and the traditional ideological and political education of language differences, forming a communication barrier. Such as "hate" ("like, not hate"), "CU" ("goodbye"), 7456" ("I am so angry") and so on, the University of Ideological and political education practitioners, estimated as in "paradise". Only fully understand the education of college students network language, adapt to it and really into the students the language form, can be more keen to capture the dynamic change of thought of college students and grasp the psychological status of the college students.

\subsubsection{Learning network language}

Educators have a learning network language awareness, to actively take the initiative to understand learning network language, network and the cultivation of good language skills. On the one hand, educators should expand the traditional education idea. The use of network language to the innovative education mode, constantly updated the work idea and innovate methods of work, the application of active network language to meet the requirements of modern ideological and political education. On the other hand, educators should have the courage to the network language is used in the practice of education. Can pass on creativity of college students love to see and hear the network language to communicate with them, using Micro message, micro-blog, QQ network, to understand their way of life and values, so as to improve on their thinking and behavior to master.

\subsection{Colleges students establish healthy network literacy}

Colleges and universities should pay attention to, from the perspective of university education itself, to guide the education, to ensure the students establish a positive and healthy network literacy.

\subsubsection{Improving the resolution ability of college students on network language}

Colleges and universities should be the network language use and the ideological and political theory course combination, of the basic knowledge education for university students, offering relevant moral civilization construction and the legal teaching curriculum, to carry out the relevant lectures and seminar activities, continue to strengthen the college students' network civilization consciousness, the norms of behavior criterion and moral standards in the mind of students not consciousness, enhances the ability to distinguish the impact of college students on the negative network language, help students form healthy network language view.

\subsubsection{Improving the self-discipline ability of college students on network language}

The network language college students must follow the "absorbing its essence, to its dregs" principle, there will be vitality, full of the breath of life, of conducive to social development, carry forward the national culture to develop network vocabulary, network language is shut sb. vulgar, unhealthy. Let the students identify, judge the network language beauty of good and evil, make the right moral judgment consciousness of current network popular language, let students strengthen their moral awareness, moral consciousness of the network language, and create a positive and healthy network personality.

\subsection{Constructing supervision mechanism of network language}

Construction of supervision mechanism of network language, is an important measure to prevent undesirable network language wanton development, is conducive to the healthy development of network language, but also an important guarantee for the harmonious development of network culture.

\subsubsection{Countries formulate relevant laws and policies}

Our country for the standardization of network language, not only to strictly formulated relevant policies and regulations, should be more effective and resolutely implement the policies and regulations, to avoid a mere formality, the enforcement of the law is too simple and lead to lack of supervision. Should use the sound law of compulsory elimination of network language rubbish. In particular, some of the major websites, such as Sina, Net Ease etc., should take the lead in the use of network language civilization, strengthen the rules for the supervision of network language; some shopping website taobao.com, such as dangdang.com, Jingdong mallshould be occupied shielding network argots and the shopping fast and brings the network language; some chat software, such as Micro message Renren, QQ software should be on the basis of the existing mechanism, make special provisions for the use of network language, avoid becoming negative using network language guide. 


\subsubsection{Colleges coordinate with the relevant departments to strengthen supervision of network}

Management of network technology through the establishment of campus network management system, the online access management, IP address management, user account management functions to strengthen the network supervision system, taking the strict constraints and curb adverse remarks. The language violence cause bad influence and serious consequences, should be given severe criticism and education and serious, severe cases can investigate its related legal liability. As colleges and Universities Forum can be the implementation of the real name system management, such as the registration approach through the real information using the student number, personal information such as, can have the network speech right. You can also through the design of a network filter similar "firewall" program or software, the rules for the network language, and the shielding, delete.

\section{REFERENCES}

[1] Guo liying, The Influence of the Network on the Ideological Education of College Students and the Countermeasures, Education Exploration, 2008, (05),56-58

[2] Yang yanbao, Analysis of the Current Situation of College Students' Network Language Using, Cultural and educational information, 2009, (09), 25-27

[3] Zhang Xiaorong, On the Value and Application of Network Language to University Students Ideological and Political Education, Journal of Sichuan University of Science and Engineering, china, 2012, (02), 98-102

[4] Jia Bo, Negative Influence of Network on College Students' Ideological and Political Education and the Countermeasures, 2013, (02),73-76

[5] Shi yaying, Features of Network Language and its Influence on College Students, Chinese Journal, china, 2014, (06), 43-44 